Pragmatics 9:1.5-20 (1999)

International Pragmatics Association

DOI: $10.1075 /$ prag.9.1.02wat

\title{
LANGUAGE AND POLITENESS IN EARLY EIGHTEENTH CENTURY BRITAIN
}

\author{
Richard J. Watts
}

\section{Introduction}

In 1698 Daniel Defoe published his Essay on Projects, most of which dealt with economic topics. One of them, however, was a project to establish a language academy in Britain along the lines of the Académie Française, thus predating Swift's famous Proposal for Correcting, Improving and Ascertaining the English Tongue by 14 years. Defoe proposes that 'a society be erected by the King himself' and that it should be composed of 'none but persons of the first figure in learning'. Defoe specifies that the work of this society

should be to encourage polite learning, to polish and refine the English tongue, and advance the so much neglected faculty of correct language, to establish purity and propriety of style, and to purge it from all the irregular additions that ignorance and affectation have introduced; and all those innovations in speech, if I may call them such, which some dogmatic writers have the confidence to foster upon their native language, as if their authority were sufficient to make their own fancy legitimate. (Defoe 1698, in Bredvold et al. [1933] 1955: 3)

'Polite' learning is closely associated here with 'polishing' and 'refining' the English language and with establishing the 'purity and propriety of style'. It is placed in opposition to 'ignorance and affectation' and to 'innovations in speech'.

Later in the essay Defoe, still considering who should be allowed to participate in his 'society', makes an interesting distinction between 'persons eminent for learning', who should be admitted, and persons 'whose business or trade was learning', who should be excluded. In this latter group Defoe includes 'many great scholars', who are 'mere learned men', and

graduates in the last degree of study, whose English has been far from polite, full of affectation, hard words, and long unusual coupling of syllables and sentences, which sound harsh and untunable to the ear, and shock the reader both in expression and understanding. (Defoe 1698, in Bredvold et al. [1933] 1935: 3-4)

'Scholars' and university graduates, today's professional academics, are excluded here from the select group of those whose English is said to be 'polite'. The kind of English that does not qualify for inclusion in the category of 'polite English' is that which is 'full of affectation', an important term which will concern us further in the following section, that which is 'full of harsh words', although Defoe provides no definition of what he means by the term, and that which contains 'long unusual coupling of syllables and sentences', not because of the syntactic problems involved in processing them but because of a lack of 
aesthetic refinement - they 'sound harsh and untunable to the ear' - which might 'shock' the reader's sensibilities.

I shall argue in this paper that the term 'polite' in the early eighteenth century in Britain, particularly when it was connected with language use, was manipulated in a socially selective way, i.e. that politeness was an attribute of the legitimate language variety within the early eighteenth century linguistic marketplace in Britain, access to which was equivalent to access to high social status from which power could be exercised. It was, in other words, part of the ideological discourse of standardisation. But I shall also argue that determining who was a member of 'polite society' was likewise in the hands of those who had already gained access. Defoe makes this quite explicit at one point:

I would therefore have this society wholly composed of gentlemen, whereof twelve to be of the nobility, if possible, and twelve private gentlemen, and a class of twelve to be left open for mere merit, let it be found in who or what sort it would, which would lie as the crown of their study, who have done something eminent to deserve it. (Defoe 1698, in Bredvold et al. [1933] 1935: 4)

The nobility and the gentry are thus qualified to decide on what should be deemed 'polite English', and the implication is that they should also decide on which twelve scholars are worthy of admission to the society, thereby completing their number. ${ }^{1}$

In addition, I shall also show how the concept of 'politeness' in early eighteenth century Britain had already been subtly changed from the second half of the seventeenth century, when it was taken over from French conduct writers such as La Bruyère, the Abbé Bellegarde and Antoine de Courtin (cf. Ketcham 1985: ch. 2). In the first half of the eighteenth century, as part of the prescriptivist efforts to standardise English, politeness was repeatedly connected with language use as a marker of social class. I shall suggest that the perception of politeness as a social class marker has not entirely disappeared from the Britain of today and that models of linguistic politeness such as Brown and Levinson ([1978] 1987) are effectively models of second-order politeness (cf. Watts et al. 1992: Introduction) which do not take account of first-order lay conceptualisations of the term and do not help us to unravel the complexity of connection between politeness, social class, educatedness, learning, etc.

\section{The 'honnête homme' and Descartes' physiological metaphor}

In his Discours de la Méthode, first published at Leiden in 1637, René Descartes postulated that human beings consisted of a body and a soul, or mind (depending on how one translates the French lexeme âme), and that it was the soul/mind which distinguished humans from animals. In order to conceptualise the relationship between body and soul/mind more clearly, Descartes used the metaphor of the moving machine, or automaton, which in the 17 th century would undoubtedly have been driven by clockwork with springs, cogwheels, etc., to refer to the movements, gestures and postures of the human body. The movements made by the animal automaton were under the control of 'passions intérieures'. The major distinction between animals and humans, however, resided in the human capacity for thought and language. For Descartes this was the âme, which, rather than being like a 'pilote en son navire' (Descartes [1637] 1973: 159), was independent of the body and would therefore not die with it. 
The French conduct writers in the last twenty to twenty-five years of the seventeenth century adapted Descartes' metaphor to Cicero's concept of the honestus vir (honnête homme) and postulated a direct relationship between the mechanical functioning of the individual human body and the state of that person's soul. Ketcham (1985: 50) quotes the following passage from the English translation of the Abbé Bellegarde's Reflexions upon the Politeness of Manners:

... there's so great a Correspondence betwixt those Springs that move the Heart, and those that move the Countenance; that we may judge by this outward Dial-plate, how the Clock-work goes in the Soul. ([1698] 1717: 40)

The harmonious correspondence between the body and the mind/soul, i.e. the perfect union between an individual's outward behaviour (the body) and her/his character (the mind/soul), was termed 'politeness' or 'modesty' and the disharmony or disjunction of body and soul/mind was termed 'affectation' (cf. Ketcham 1985: 50). Bellegarde defines 'affectation' in the following way:

Affectation is the falsification of the whole Person, which deviates from all that is Natural, whereby it might please to put on an ascititious Ayre, wherewithal to become Ridiculous ... People corrupted with this Vice, have nothing natural in their way of Talking, Walking, Dressing, turning their Eyes or Head, these are Motions unkown to other Men. ([1696] 1717: 58, in Ketcham 1985: 50-51)

Politeness is therefore a 'natural' quality, in opposition to affectation, and both are revealed in an individual's actions and, above all else, in her/his words. So right from the outset language use is taken as an indicator of that harmony between body and soul known as 'politeness'.

There is a major problem with this definition of politeness, however. If politeness is natural and is the harmonious union between the body and the soul, would we not have to say that a person with an evil soul, whose behaviour 'naturally' reflects this character, is also polite? Clearly, this is not what the conduct writers are trying to suggest. Instead, they posit that the perfect union between body and soul is a virtue, not a vice. Hence, only if an individual is naturally good, can we talk of 'politeness'.

Bellegarde goes one step further and posits that the virtue of politeness should 'have its Principle in the Soul, as being the Product of an accomplish'd Mind, centring on it self, and Master of its Thoughts and Words' ([1698] 1717: 2, in Ketcham 1985: 51). In other words, in order to rescue the concept of politeness, it is necessary to make a division between the soul and the mind, such that the soul (which we might correlate roughly here with the notion of character) is the product of the mind, but only after this has been refined or polished, i.e. has become 'accomplish'd'.

But this contradicts the principle that politeness is natural. Polishing one's mind, or having it polished for one, is a social process, a process of education and acculturation. The kind and degree of accomplishment which is the goal of the process is socially, indeed ideologically, constructed, and since it is determined not by the individual her/himself but by repeated habitual interactions with others, it is socially reproduced and is therefore institutionalised.

In fact, Bellegarde contradicts his earlier assertions about the ideal harmony between the 'accomplished', self-possessed mind and exterior behaviour in the examples he gives, which display individuals almost wholly concerned to please others by carrying out actions 
(including modes of language usage) intended to influence them. He gives a second definition of the polite individual as one who 'puts on all Appearances, and transforms himself into all Shapes, the better to gain his Point' ([1698] 1717: 2), the purpose being to 'purchase the Esteem and Affection of Men' ([1698] 1717: 39).

In the conduct writers, and in particular in Bellegarde's work, we can already identify the following self-contradictory and somewhat confusing aspects of politeness:

1. Politeness is the ideal union between the character of an individual and her/his external actions (e.g. the language which that individual uses).

2. Politeness is the ability to please others through one's external actions (e.g. through one's language usage).

3. Politeness is a natural attribute of a 'good' character.

4. Politeness is a socially acquired state of mind which is adjudged to have reached a state of being 'polished' and of thereby being in conformity with a set of socially accepted forms of behaviour.

The contradictions evident here make it possible to argue that an individual is born polite, i.e. that there is a natural connection between her/his soul $/ \mathrm{mind}$ and bodily actions (including language usage). On the other hand, it is just as easy to argue that a person may acquire the ability to please and influence others whatever the circumstances of that person's birth. They also make it very easy to argue that politeness can only be acquired if one is socialised into the 'correct' set of socially accepted norms, i.e. if one is born into the appropriate social class, and therefore that those who are born outside that class can never acquire politeness. The opposite notion of 'affectation' can always be used to categorise the behaviour of those who are not class members.

I shall argue in the present paper that it is precisely this social interpretation of politeness which was taken up by writers on language, morals, society and philosophy in Britain, and that the claim that politeness is a natural attribute of certain individuals and not of others is used to exclude the latter from the ranks of the former. In $18^{\text {th }}$ century Britain politeness is thus caught up in a discourse that I shall call the 'ideology of gentrification'. In addition I shall argue that, within this discourse, language behaviour was interpreted as one of the most significant markers, if not the most significant marker, of politeness. In addition I shall show that 'the ideology of gentrification' becomes inextricably linked with what Milroy and Milroy (1985) have called 'the ideology of standard English'. The link became so strong that 'standard English' became almost synonymous with 'polite English' or 'the English of polite society', and even found its way into some of the prescriptive grammar books of the 18th century.

\section{Gentrifying philosophy}

We saw in the introductory section of this paper that Defoe excluded as members of his projected 'society' for the 'polishing' and 'refining' of the English language the academic establishment, i.e. scholars at the two universities of Oxford and Cambridge, unless they were specifically elected by the 24 members already elected. These first 24 members should be chosen from the ranks of the nobility and the gentry. This might seem contradictory until we consider that throughout the 17th century, from the time of Francis Bacon, conflict had arisen between, on the one hand, those following a purely scholastic, syllogistic mode of argument in 'scientific investigation' in which, in the tradition of the 
Renaissance, the ancients were credited with having already discovered the principal 'laws of nature and the universe', and, on the other hand, those who were interested in questioning nature directly, i.e. by experimentation, observation, manipulation, etc. The former, the scholastics, were associated with the universities whereas the latter, the experimenters or the 'virtuosi', were associated with or became members of the Royal Society of London, which was granted its charter by Charles II in 1662.

From the outset the Royal Society, although it did not explicitly set itself up against the universities, saw itself as the heir to Bacon's utopian House of Salomon in the New Atlantis, in which he forecast 'the triumph of the new empiricism' (Cope and Jones 1958: xii). Some of the founding members of the Royal Society, like John Wallis and John Wilkins, were associated with the universities, but the majority were private individuals, most of them from the gentry and some from the nobility. Thomas Sprat, in his History of the Royal Society has the following to say about its composition:

But, though the Society entertains very many men of particular Professions; yet the farr greater Number are Gentlemen, free and unconfin'd. By the help of this there was hopefull Provision made against two corruptions of Learning, which have been long complain'd of, but never remov'd: The one, that Knowledge still degenerates, to consult present profit too soon; the other, that Philosophers have bin always Masters, \& Scholars; some imposing, \& all the other submitting; and not as equal observers without dependence. (1667: 67)

With the term 'philosophers' Sprat is referring to 'masters and scholars' in the universities, and the guarantee against both the degeneration of knowledge and its esoteric isolation in the universities is that 'the farr greater Number [of the members of the Royal Society] are Gentlemen'. 'Natural philosophy' was therefore the domain of gentlemen scholars, of intelligent, inquisitive and enthusiastic amateurs rather than professional academics, and that is precisely the point of view that Defoe puts forward in his project for a society for the polishing and refining of the English language.

At a later point in the History of the Royal Society Sprat, giving a historical account of the development of learning from the classical period to the 17th century, suggests the following reason for learning being 'the first thing, that was constantly swept away, in all destructions of Empire, and forein inundations' (1667: 118):

\begin{abstract}
It is, because Philosophy had been spun out, to so fine a thread, that it could be known but only to those, who would throw away all their whole Lives upon it. It was made too subtile, for the common, and gross conceptions of men of business. It had before in a measure been banish'd, by the Philosophers themselves, out of the World; and shut up in the shades of their walks. And by this means, it was first look'd upon, as most useless; and so fit, soonest to be neglected. Whereas if at first it had been made to converse more with the senses, and to assist familiarly in all occasions of human life; it would, no doubt, have been thought needful to be preserv'd, in the most Active, and ignorant Time. (1667: 118-119)
\end{abstract}

Writing on behalf of the Royal Society, Sprat perceived a need to make philosophy accessible to those who were not professional scholars, and this meant using a style of language that he defines as a 'natural way of speaking', 'preferring the language of Artizans, Countrymen, and Merchants, before that, of Wits, or Scholars' (1667: 113).

However, what Sprat and his fellow members of the Royal Society in its early days must have thought of as a popularisation of philosophy had, with an increasing number of members coming from the ranks of the nobility and the gentry, effectively become a 
'gentrification' of philosophy by the end of the seventeenth century. This meant taking philosophy out of the scholar's study and putting it into the 'polite' world of the gentleman's drawing-room, making it, in fact, part of what it meant to be 'polite'. This is nowhere more obvious than in the works of Anthony Ashley Cooper, the 3rd Earl of Shaftesbury, whose work spans the period from 1699 to 1710 and consists of essays which were collected and published together in 1711 under the title Characteristics of Men, Manners, Opinions, Times. An Inquiry Concerning Virtue or Merit.

Shaftesbury's argument is that humans, as individuals, are driven towards their own 'self-good', but that, since they are also social animals, conflict between 'private interest' and 'public good' leads to what he calls 'vicious affection'. As a consequence 'a creature cannot really be good and natural in respect of his society or public, without being ill and unnatural towards himself' (Shaftesbury 1711: Book I, Part II, Section II, in Bredvold et al. [1933] 1955: 249). In the previous section I put forward four definitions of politeness as defined by the conduct writers. I also pointed out that the third and fourth of these contradict one another. If politeness is a natural attribute of a good character (definition 3), the 'good' can only be adjudged as good in conformity with a set of socially accepted forms of behaviour (definition 4). In other words, politeness may be the natural attribute of a good character, but it can only be termed politeness if it is a socially acquired state of mind. Precisely this contradiction emerges in Shaftesbury's definition of public good as against private good:

When in general all the affections or passions are suited to the public good, or good of the species, as above mentioned, then is the natural temper entirely good. If, on the contrary, any requisite passion be wanting, or if there be any one supernumerary or weak, or anywise disserviceable or contrary to that main end, then is the natural temper, and consequently the creature himself, in some measure corrupt and ill. (Shaftesbury 1711: Book I, Part II, Section II, in Bredvold et al. [1933] 1955: 251)

Hence, if all of an individual's 'affections or passions' benefit the public good, then that individual's 'natural temper' (to use Descartes' term, that person's âme) is good. If anything is missing from that perfect fit with the 'public good', then it does not matter whether or not the person's 'affections or passions' benefit his/her private good, that person is 'in some measure corrupt and ill'.

At this point, we might question what this has to do with politeness in Shaftesbury's philosophy. In Book III of Characteristics of Men, Manners, Opinions, Times (Miscellany), Shaftesbury creates a fictive narrator commenting on and supporting his (Shaftesbury's) own philosophy. In Chapter II of the Miscellany the narrator states that Shaftesbury's, and his, aim is '.. to advance philosophy (as harsh a subject as it may appear) on the very foundation of what is called agreeable and polite' (Shaftesbury 1711: Book III, Miscellany, Chapter II, in Bredvold et al. [1933] 1955: 267). On the basis of this credo, he suggests a 'joint endeavour':

Our joint endeavour, therefore, must appear this; to show 'that nothing which is found charming or delightful in the polite world, nothing which is adopted as pleasure or entertainment, of whatever kind, can any way be accounted for, supported, or established, without the pre-establishment or supposition of a certain taste.' (ibid.)

Shaftesbury's philosophy is therefore aimed at the 'polite world', and it is also educational and moralistic. Taste is a large part of what it means to be a polished member of society, 
but that taste is not simply taste in outward appearances and behaviour but also taste in morals:

Let us therefore proceed in this view, addressing ourselves to the grown youth of our polite world. Let the appeal be to those whose relish is retrievable, and whose taste may yet be formed in morals, as it seems to be already in exterior manners and behaviour. (Shaftesbury 1711: Book III, Miscellany, Chapter II, in Bredvold et al. [1933] 1955: 272)

In addition, decorum and grace in outward appearance, movements and behaviour are all attributes of politeness, as is a love of beauty, symmetry and order. At a number of points in his writings Shaftesbury also explicitly combines gentility, i.e. being a member of the social class of the gentry, with politeness. All these elements are present in the following quotation from the Miscellany:

\footnotetext{
Whoever has any impression of what we call gentility or politeness is already so acquainted with the decorum and grace of things that he will readily confess a pleasure and enjoyment in the very survey and contemplation of this kind. Now if in the way of polite pleasure the study and love of beauty be essential, the study and love of symmetry and order, on which beauty depends, must also be essential in the same respect. (Shaftesbury 1711: Book III, Miscellany, Chapter II, in Bredvold et al. [1933] 1955: 273)
}

The language programme of the Royal Society, contained as it is in Sprat's History, insisted on a 'natural way of speaking', and presumably writing, which would be close to 'the language of Artizans, Countrymen, and Merchants, before that, of Wits, or Scholars'. The process of gentrifying philosophy, however, leads to a conception of language use in which decorum, grace, beauty, symmetry and order are now the main features defining polite language, or the language of polite society.

Shaftesbury thus shifts the focus of a 'natural way of speaking' to the language behaviour of polite society, which includes all these attributes, and provides what almost amounts to a programmatic blueprint for dealing with language and politeness throughout the rest of the 18th century and well into the 19th. Precisely what kind of behaviour, including language behaviour, counted as exemplars of 'decorum', 'grace', 'beauty', 'symmetry' and 'order', however, could only be decided by members of the social classes of the gentry and the nobility themselves.

In terms of language use, therefore, legitimate forms of language were socially constructed and reproduced by members of polite society, but at the same time what counted as 'politeness' could also be reconstructed. As the 18th century progressed, forms of legitimate language usage were conceptualised as prescriptive rules of language behaviour and were transformed into the rules of 'standard English'. In the following section I shall sketch out the change in the notion of 'legitimate language' that took place at the end of the 17th and beginning of the 18th centuries and then illustrate the results of this transformation through the work of one prescriptive grammarian of English.

\section{Polite language as the 'legitimate language' in 18th century Britain}

In Watts (in print a) I discuss the way in which standard English is socially constructed as the 'legitimate language' during the 18th century by the discourse community of 
prescriptive grammar writers. The term 'legitimate language' has been taken from the work of Pierre Bourdieu, who suggests that a culture functions by producing and reproducing three different kinds of capital, material capital (involving the economy and the production of material goods), cultural capital (involving different forms of knowledge, acquired abilities, competence and skills) and symbolic capital (involving social status, honour, fame, respect, prestige, etc.), all of which function in different kinds of 'marketplace'.

Various kinds of resource are necessary to acquire these forms of capital, the major type of resource in the area of symbolic capital being language. However, the types of resource necessary to acquire capital can vary in their forms and each form can have a greater or lesser value than another form. In the case of language, highly valued forms of language give the user of those forms access to economic and cultural marketplaces. With reference to the linguistic marketplace, Bourdieu talks of 'legitimate language', i.e. that language which has acquired a place of preeminence through forms of institutional discourse.

Individuals can be socialised into the ways in which they should comport themselves within any one marketplace, whether economic, cultural or symbolic. The 'feel' for a situation which an individual needs to gain in order to react accordingly is referred to by Bourdieu as a habitus. Bourdieu and Passeron (1994: 8) state that '[1]anguage is the most active and elusive part of the cultural heritage', thereby implying that the 'linguistic habitus' is one of the most salient in social interaction and one of the most difficult to change.

The term 'legitimate language' refers not only to a highly valued, officially sanctioned linguistic code, but also to the forms of discourse which characterise the social institution concerned. In the case of the social classes of the gentry and the nobility in the 18th century, the legitimate language code is 'standard' English and the legitimate forms of language behaviour are those which define the habitus of the gentleman, i.e. polite language. The other principal behavioural attributes of the habitus are also constructed socially, and, together with the 'legitimate language', they serve as a means to admit members to the social classes of the gentry and the nobility or, alternatively, to exclude them.

However, as we saw in the previous section, between the time when Sprat published his History of the Royal Society in 1667 and the time when Defoe published his Essay on Projects some thirty years later in 1698, a fundamental social reconstruction had taken place in the conceptualisation of the 'legitimate language'. Elsewhere I have outlined the mythical strands that formed part of the ideology of prescriptivism in the 18th century (Watts in print $b$ ) and have identified a significant reversal in the weighting of some of those strands at the end of the 17th century. For example, in 1688 Guy Miège published The English Grammar, in the preface to which he took over, almost verbatim, part of a text by Richard Carew entitled 'The Excellency of the English Tongue' which appeared as a chapter in William Camden's Remains of Britain (1586). Carew praises what he calls the 'copiousness' of the English language to be seen 'in the diversity of our Dialects'. The fact that Carew's text was frequently copied by authors on English in the 17th century, and, for all we know, may itself have been the copy of an earlier text, indicates that the great variety of dialects within England was considered as a positive facet of the language, and I have used the term 'the myth of variety' to characterise it.

Miège writes the following: 
Nor does its Abundance ly here [i.e. in the fact that English has borrowed liberally from other languages]. For we have Court and Country English, Northern and Southern Dialects; which differ not only in Pronunciation, but also in Words and Terms. (1688: A4)

However, Bailey (1991) argues that, with respect to varieties of English, two competing discourses were in evidence since the 16th century, the one that I have chosen to call 'the myth of variety' and the other being what Bailey calls the discourse of 'right English' represented by writers on the language such as Bullokar (1580) and Gill (1621), who considered the use of dialects as a form of 'barbarism'. Some time between 1688 (Miège) and 1698 (Defoe) the balance swung in favour the discourse of 'right English'. I would like to argue that the discourse shift which resulted in a disparagement of the dialects and the promotion of 'court' English is a direct reflection of the gentrification of philosophy (and thereby of English) as I have outlined this process in the previous section.

In the following section I shall briefly show how this fits with the construction of social values represented in the Whig literary periodicals from 1711 on, in particular in The Spectator, and then show how 'grammar' and 'politeness' were explicitly connected in the work of Hugh Jones (1724), whose grammar, the first 'colonial' grammar of English, was published in London just 36 years after Miège, but written in Williamsburgh, Virginia. Before I do so, however, let us briefly consider which of the two discourses is championed by Jones:

For want of better Knowledge, and more Care, almost every County in England has gotten a distinct Dialect, or several peculiar Words, and odious Tones, perfectly ridiculous to Persons unaccustomed to hear such Jargon: thus as the speech of a Yorkshire and Somersetshire downright Countryman would be almost unintelligible to each other; so would it be good Diversion to a polite Londoner to hear a Dialogue between them. (Jones 1724: 11-12)

The 'myth of variety' has been well and truly supplanted here by the discourse of 'right English', but not only that: note how Jones suggests that the 'polite Londoner' would find great amusement in listening to people conversing in rural dialects. The tell-tale word is of course 'polite'. Jones goes on to classify the variety of dialects as a 'Confusion of English', but in listing five principal types of English, he also includes the 'Proper, or London Language', not of course meaning the English of the East End of London, but rather the English of the Royal Court. The 'polite Londoner' can be assumed to be a member of the gentry and the language variety which Jones goes on to praise is the English of polite society:

Out of this Confusion of English may we collect 5 principal Dialects and Tones.

1. The Northern Dialect, which we may call Yorkshire.

2. The Southern, or Sussex Speech.

3. The Eastern, or Suffolk Speech.

4. The Western, which we may call Bristol Language.

5. The Proper, or London Language.

All these are manifestly distinguishable by their Sound, and some Terms, to any curious Observator. (1724: 13)

The change that led to the 'the myth of variety' being inverted by the discourse of 'right English' and to the social reconstruction of the 'legitimate language' as the 'polite' language of the court was a consequence of the gentrification of philosophy and learning 
by means of which the principles of polite behaviour, 'decorum', 'grace', 'beauty', 'symmetry' and 'order', became the social symbols for membership in the class of the gentry.

\section{From The Spectator to Hugh Jones}

These social symbols were nowhere more clearly presented than in the two literary periodicals The Tatler and The Spectator, the first initiated by Richard Steele, but in which Joseph Addison contributed several numbers, the second initiated by Addison with contributions by Steele. One of the main aims of both these Whig periodicals was to reach as large a reading public as possible, given the constraints of daily printing and their dissemination from within London. McCrae (1990: 34) suggests that

[w] hether Addison and Steele explain the great philosophers, associate activities that we now separate, or domesticate satire, the touchstone for their work remains their commitment to popularity. Pursuing popularity, they cast themselves in the role of explainers and demystifiers.

Their commitment to as large a readership as possible led them to espouse a form of 'Plain English' that would be understandable to that readership. It was a variety of English in which words are taken 'to be the "representation of speech," and speech to be the representative of truth' (McCrae 1990: 42).

On the other hand, as Ketcham (1985) points out, the essays of The Spectator 'reflect assumptions about the structures of social life which in turn reveal changing images of social man in the early eighteenth century' (1985: 3). Ketcham argues that Addison, Steele and the other contributors to The Spectator were actively trying to "establish rather than question an idea of social order' (ibid.: 5) and that they were doing so not to test or comment on social conventions or the language in which they were purveyed, but actually to establish those conventions. The way in which the character of Mr Spectator is constructed and allowed to comment on and act as a filter through which the reader could judge a variety of forms of social behaviour supports Ketcham's argument and detracts from McCrae's interpretation that they were only angling for popularity.

If we now ask what social order and which social conventions Addison and Steele were consciously trying to construct, a careful examination of The Tatler and The Spectator reveals a 'sympathetic respect for the commonplaces of daily life' (Ketcham 1985: 5), the touchstone of which is the continual attempt to relate outward behaviour to inward character. It is clear, therefore, that the principle of politeness as representing a natural connection between an individual's character and her/his actions (including the individual's variety and style of speech) is the main component in a conscious strategy by Addison and Steele to construct the idea of social order. This, in turn, is closely linked to the attempt to gentrify philosophy, as is explicitly stated in Spectator 10:

It was said of Socrates, that he brought Philosophy down from Heaven, to inhabit among Men; and I shall be ambitious to have it said of me, that I brought Philosophy out of Closets and Libraries, Schools and Colleges, to dwell in Clubs and Assemblies, at Tea-Tables, and in Coffee-Houses.

The periodicals of the second and third decades of the eighteenth century in Britain were immensely influential in helping to construct social conventions, in particular those of 
politeness as we have defined the term in this article. They were in fact one of the major sites for the cultural reproduction of polite behaviour and its intimate connection with social class differentiation and the emergence of standard English as a class 'dialect'. I shall now illustrate the effects of this potent, and, in terms of the current vitriolic debate over standard English in Britain (cf. Honey 1997), fatal, connection by briefly looking at Hugh Jones's 1724 grammar of English.

Jones's Accidence to the English Tongue was published in London in 1724, although Jones describes himself in the frontispiece as 'lately Mathematical Professor at the College of William and Mary, at Williamsburgh in Virginia; and Chaplain to the Honourable the Assembly of that Colony'. It is therefore not clear whether Jones had returned to Britain at the time when his grammar was published or whether he was still in Virginia. The grammar encompasses just 69 pages, which are divided into five parts, Part I 'Of English Letters' (pp. 2-15), Part II 'Of English Syllables' (pp. 15-19), Part III 'Of English Words' (pp. 20-38), Part IV 'Of English Sentences' (pp. 39-41) and Part V 'Of English Discourse, or Speech'.

Just over a third of the grammar was therefore devoted to what Jones calls 'English Discourse, or Speech' and even a brief look at the topics of Part V and the way in which Jones presents those topics reveals that, apart from a description of discourse as being composed of sentences and a list of rhetorical tropes with examples, they are in fact rules of how to behave linguistically in a socially acceptable way. The subsection entitled 'Of Delivery' immediately adopts a prescriptive tone:

In Delivery you must regard ${ }^{\mathrm{st}}$. The Quantity, $2^{\mathrm{dly}}$. the Accent; $3^{\mathrm{dly}}$. the Emphasis.

On p. 22 Jones tells his reader that

... it is to be wished, that a Publick Standard were fix'd; as a Touchstone to true English, whereby it might be regulated, and proved, which alone might give License to Persons, and Occasions to make Additions, or Corrections.

Jones makes a difference here between a 'Publick Standard' and 'true English'. The form, or grammar, of the language, 'a Publick Standard', should be used to evaluate whether individual speakers/writers are using the language 'truly', i.e. whether their linguistic behaviour is socially acceptable or not. Note here also that Jones, like Defoe, would like to see English 'regulated, and proved', although he does not make it entirely clear who should be responsible for fixing the standard.

From p. 51 till the end of the text Jones's grammar abounds with descriptions of socially acceptable forms of linguistic behaviour and the rules that individuals should follow in order to produce them. A set of lexemes runs through Jones's discourse creating a complex Leitmotif of the standards of linguistic behaviour an individual speaker should aspire to achieve, and they correspond very closely to the 'assumptions about the structures of social life' presented by The Tatler, The Spectator and its successor The Guardian: 'polite', 'accomplished', 'learned', 'correct', 'pure', 'good manners', 'reason', 'modesty', 'decency', etc.

Three extracts from Jones's grammar will illustrate this point:

When we are disposed to be pleasant, we may be merry, and wise. We may use jocular Diversion, facetious Turns, entertaining Stories, smart Repartees, good Humour, and cheerful Conversation; without 
punning Witticisms, stupid Conundrums, excessive Laughter, monstrous hyperbolical Romances, atheistical Discourse, diabolical Burlesque, sharp Satyrs, and injurious Lies; without severe Criticisms, censorious Remarks, ill-natured Contradiction, jarring Disputes, quarrelsome Broils, orfoolish, vain and noisy Babbling, or riotous Revelling, with due Respect to Religion, Virtue and Reason; hating all rude, wicked, and prophane Discourse. None of good Manners use nasty Expressions, and foul vulgar Terms, which are nauseous, and odious; for (particularly) Obscenity betrays a corrupt Heart void of Reason, and Goodness; for

Immodest Words admit of no defence;

Since Want of Decency is Want of Sense. (p.56-57)

To be an accomplished conversationalist, therefore, one must be

+ pleasant

+ merry

+ wise

allowing one to use

+ jocular diversion

+ facetious turns

+ entertaining stories

+ cheerful conversation.

In carrying out 'pleasant conversation' one should avoid using the following:

- punning witticisms

- stupid conundrums

- excessive laughter

- monstrous hyperbolical romances

- atheistical discourse

- diabolical burlesque

- sharp satyrs

- injurious lies

- severe criticisms

- censorious remarks

- ill-natured contradiction

- jarring disputes

- quarrelsome broils

- foolish, vain and noisy babbling

- riotous revelling

Jones reflects precisely the definition of politeness set up by the conduct writers and disseminated in Britain in the early 18th century by writers such as Shaftesbury, Steele and Addison, viz. that 'there's so great a Correspondence betwixt those Springs that move the Heart, and those that move the Countenance; that we may judge by this outward Dial-plate, how the Clock-work goes in the Soul' (Bellegarde [1698] 1717: 40) or 'that nothing which is found charming or delightful in the polite world, nothing which is adopted as pleasure or entertainment, of whatever kind, can any way be accounted for, supported, or established, without the pre-establishment or supposition of a certain taste' (Shaftesbury 1711: Book III, Miscellany, Chapter II), when he maintains that 'none of good Manners use nasty Expressions, and foul vulgar Terms, which are nauseous, and odious; for (particularly) Obscenity betrays a corrupt Heart void of Reason, and Goodness'. In Jones politeness is intimately interwoven with the concept of socially appropriate discourse, this being the 'true English' which provides the touchstone to a 'Publick Standard'. 
In the subsection 'Of Disputation, and Conference', Jones makes the following point:

Our Language affords us Choice of Words, and Variety of Expression; in which we should imitate the Learned and Polite, the Correct and Pure, without jingling Terms, harsh or obsolete, vulgar or unbecoming Words, ungrateful to the Ear, difficult in Sound, or offensive to Modesty, good Manners, or good Sense. (p. 62)

Acquiring the ability to speak 'true English' involves imitating the 'learned' and 'polite', which is in turn put into juxtaposition with the 'correct' and 'pure'. Anything which is 'offensive to Modesty, good Manners, or good Sense' is thus the counterpoint to polite and learned behaviour and to correct and pure language.

A little later in the same subsection the connections between 'correct language', 'polite and learned behaviour' and good manners are made even more explicit:

Practice is highly instrumental in advancing Persons to any Degree of Perfection in our Language; Great Improvement being made by learned Conversation, and ingenious and polite Correspondence: or else by reading, transcribing good Authors; or by indicting Letters, or making Themes and Essays upon any Subject ... (p. 65)

These qualities, put forward by Jones as being desirable in polite society, i.e. the gentry and the nobility, can be acquired by any individual willing to improve him/herself by 'learned Conversation' and 'ingenious and polite Correspondence'. They can also be acquired, amongst other means, by 'reading' and 'transcribing good authors', and it is here that we see one of the first explicit mentions of the intricate interconnection between ideas of politeness, the emergence of an ideology of standard English (cf. Milroy and Milroy 1985), the social stratification that led to the gentrification of philosophy and language use, and the recourse to 'good authors' as a model of language use to be followed.

\section{Conflicting notions of politeness in Britain}

It has been my aim in this article to trace out how the concept of politeness in Britain was developed from the French conduct writers and how it was conceptualised in the last ten to twelve years of the seventeenth and the first twenty years of the eighteenth century. I have argued that the shift from Sprat's 'natural way of speaking' as the recommended form of language to be used in the Royal Society in its early years, in which 'the language of Artizans, Countrymen, and Merchants' was preferred to 'that, of Wits, or Scholars', to the gentrification of philosophy (hence also the gentrification of the language of scientific enquiry outside the universities) corresponds neatly to a discourse shift away from the 'myth of variety' to the discourse of 'right English'. That shift was intimately connected with the notion of politeness as forming a mirror to the soul, but also, as we saw in Bellegarde's writings, with politeness as putting on 'all Appearances, and transform[ing one]self into all Shapes, the better to gain [one's] Point', the purpose being to 'purchase the Esteem and Affection of Men'.

Hence from the very beginnings of its use in English the term 'polite' was interpreted ambiguously to justify shifts in the behavioural patterns of the gentry and the nobility, later of the middle classes of society, and held up to those who aspired to the membership of higher echelons of society as being a desirable and imitatable form of social behaviour. This was the original first order, lay interpretation of the term, and despite radical changes 
in the structure of social classes in Britain during the twentieth century, it remains in the minds of most British people. The shift to a second-order sociolinguistic, sociocultural interpretation of politeness as the principal mechanism for reducing or avoiding face threatening activities (i.e. the Brown/Levinson interpretation which is still taken by most researchers as canonical) has, I maintain, not made much impact on that lay interpretation. Asked to decide whether or not strategies of negative or of positive politeness really represent instances of polite behaviour, the British informants I have asked have come down almost unanimously in favour of negative strategies and have tended to reject positive strategies. Goffman's much more subtle understanding of face as a form of self-presentation which can be used, and often is used, as a mask to hide one's real intentions or feelings promises to provide a more useful means of linking past and present notions of politeness in Britain than Brown and Levinson's model.

One indication of its promise is connected with the current discussion of what standard English is and what it isn't, whether or not a unified form of standard English can or should be advanced for the teaching of written and oral English in the British National Curriculum, and whether it is justified to represent linguists and sociolinguists as the 'enemies of standard English'. Honey's repeated definition of standard English as 'the language of literacy and of educatedness' (1997: 35) smacks suspiciously of Jones's insistence on the connections between 'learnedness', politeness and 'true English' and can perhaps best be seen as a Goffmanian mask used to cloak the author's real intentions of retaining and strengthening social elitism and exclusion.

The link between politeness and language in Britain has been one of the major forces in the formation of a powerful ideology of standard English. Even as late as 1925, Thomas Nicklin in a book entitled Standard English Pronunciation with some Notes on Accidence and Syntax makes the following set of statements:

\footnotetext{
... I will venture to contend that it is the right of everyone born in these islands, whatever the profession and whatever the property of his parents, to be taught to speak that English dialect which marks an educated man [i.e. standard English, RJW]. Nothing can be more disastrous than that the accidents of history, which have led to this dialect of the educated appearing to be a special prerogative of the wellto-do, should be regarded as irretrievable. The democratic spirit must demand for every child, however humble his parents' occupation, that he shall be taught that one common dialect which can be understood everywhere, and which is the modern representative of all that has been greatest in English learning, statesmanship, oratory, poetry, and politeness. (1925: 10-11, in Bailey 1991: 10)
}

The term 'politeness' here and elsewhere in Nicklin's book is understood in the way it has been outlined in this article. It is connected to education, learning, oratory and poetry through the ideology of standard English, although, to be fair to Nicklin, the socially exclusive nature of this alliance of concepts is roundly rejected here. The line between Nicklin's defence of standard English and Honey's is clear to see here although Honey has masked his endorsement of the socially exclusive nature of standard English through his argument that standard English is the language of the educated.

The lay conceptualisation of politeness is not simply one of face threat avoidance and/or minimisation. It is much more than that and has a long and complex history that needs to be thoroughly researched before we can get a reasonably clear view of what politeness means in Britain. 


\section{Notes}

1. At this point it is necessary to define the terms that I shall be using in this article to refer to what we might call today 'social classes'. By 'nobility' I refer to those members of society with inherited titles who possessed the hereditary right (and often the obligation) to appear at the Royal court and to sit in the House of Lords (thus including the bishops of the Church of England). The term 'gentry' should be understood to refer to a social class of hereditary landowners with or without inherited titles (although many of them received knighthoods) but without any obligation to attend at the Royal court and generally with no hereditary right to sit in the House of Lords. They therefore constituted a powerful rural based landowning class with no necessary affinities to the class that is often referred to as the 'bourgeoisie'. It is also somewhat inappropriate to use the German term 'Kleinadel' in reference to the gentry since many of them did not possess hereditary titles. The term 'bourgeoisie' is certainly not coextensive with the gentry (although there might have been overlaps) and is more frequently used in reference to the wealthy urban middle classes of cities such as London, Bath, Norwich, etc. Hence, any reference to the 'middle classes' is a reference to wealthy citizens who through their wealth and influence, however these were acquired, had been steadily gaining in social prestige since Elizabethan times and were to compete with the gentry for social standing throughout the $18^{\text {th }}$ century.

\section{References}

Bailey, Richard W. (1991) Images of English: A Cultural History of the Language. New York: Cambridge University Press.

Bellegarde, L'Abbé de (1696) L'art de connoitre les hommes. Paris.

Bellegarde, L’Abbé de ([1698] 1717) Reflexions upon the Politeness of Manners. London.

Bourdieu, Pierre (1991) Language and Symbolic Power. Edited by J. B. Thompson and translated by G. Raymond and M. Adamson. Cambridge: Polity Press

Bourdieu, Pierre (1982) Ce que parler veut dire: L'économie des échanges linguistiques. Paris: Fayard.

Bourdieu, Pierre and Jean-Claude Passeron (1994) Introduction: Language and relationship to language in the teaching situation. In Bourdieu, Pierre, Jean-Claude Passeron and Monique de Saint Martin (eds.), Academic Discourse. Oxford: Polity Press. Translated from Rapport Pédagogique et Communication, 1965, The Hague: Mouton et Cie.

Bredvold, Louis I., Robert K. Root and George Sherburn (eds.) (1932) Eighteenth Century Prose. New York: Nelson.

Brown, Penelope and Stephen Levinson (1978) Universals in language usage: Politeness phenomena. In E. Goody (ed.), Questions and Politeness: Strategies in Social Interaction. London: Cambridge University Press, 56-269. Reissued as Politeness: Some Universals in Language Usage. London: Cambridge University Press.

Bullokar, William (1580) A short Introduction or Guiding to Print. Write, and Read Inglish Speeche. (1966) Facsimile. Ed. Bror Danielsson and Robin C. Alston. Leeds: University of Leeds, School of English.

Carew, Richard (1586) The excellency of the English tongue. In William Camden, Remains Concerning Britain. London: John Russel, 1870, 42-51.

Cope, Jackson I. and Harold Whitmore Jones (eds.) (1958) History of the Royal Society by Thomas Sprat. St. Louis, MO: Washington University Studies. 
de Courtin, Antoine (1672) Nouveau traité de la civilité qui se pratique en France, parmi les honnestes gens. Amsterdam.

de Courtin, Antoine (1676) Suite de la civilité, ou, Traité du point-d'honneur et les règles pour converser et se conduire sagement avec les incivils et les fâcheux. Paris.

Defoe, Daniel (1698) Essay on Projects. London.

Descartes, René (1637) Discours de la Méthode. Leiden. Edited by Jean-François Revel, 1973. Paris: Livre de Poche.

Gill, Alexander (1621) Logonomia Anglica. Edited by Otto L. Jiriczek (1903). Strassburg: Trübner.

Honey, John (1997) Language is Power: The Story of Standard English and its Enemies. London: Faber and Faber.

Jones, Hugh (1724) An Accidence to the English Tongue. London: John Clarke.

Ketcham, Michael G. (1985) Transparent Designs: Reading, Performance, and Form in the Spectator Papers. Athens GE: University of Georgia Press.

La Bruyère, Jean de (16**) Les caractères: ou Les moeurs de ce siècle. Edited by Antoine Adam (1989). Paris: Gallimard.

Goffman, Erving (1955) On face work: An analysis of ritual elements in social interaction. Psychiatry 18: 213-231.

McCrae, Brian (1990) Addison and Steele Are Dead: The English Department, Its Canon, and the Professionalization of Literary Criticism. Newark: University of Delaware Press.

Miège, Guy (1688) The English Grammar. London.

Milroy, James and Lesley Milroy (1985) Authority in Language. London: Routledge and Kegan Paul.

Nicklin, Thomas (1925) Standard English Pronunciation with some Notes on Accidence and Syntax. Oxford: Clarendon.

Shaftesbury, Ashley Cooper, 3rd Earl of (1711) Characteristics of Men, Manners, Opinions, Times: An Inquiry Concerning Virtue or Merit. London.

Sprat, Thomas (1667) The History of the Royal-Society of London For the Improving of Natural Knowledge. London: J. Martin.

Swift, Jonathan (1712) A Proposalfor Correcting, Improving and Ascertaining the English Tongue. London. Edited by Herbert Davis and Louis Landa (1964) Oxford: Blackwell, 1-21.

Watts, Richard J. (in print a) The social construction of Standard English: Grammar writers as a 'discourse community'. In Tony Bex and Richard J. Watts (eds.), Standard English: The Widening Debate. London: Routledge.

Watts, Richard J. (in print b) Mythical strands in the ideology of prescriptivism. In Laura Wright (ed.), The History of Standard English. London: Cambridge University Press.

Watts, Richard J., Sachiko Ide and Konrad Ehlich (eds.) (1992) Politeness in Language: Studies in its History, Theory and Practice. Berlin: Mouton de Gruyter. 